\title{
Pengaruh Beberapa Campuran Media pada Feses Sapi Kaur yang Diberi Pakan Rumput Setaria dan Pelepah Sawit terhadap Biomassa dan Kualitas Vermikompos Cacing Tanah Pheretima sp
}

\author{
The Effects of Variety of Media Added on Kaur Cattle Feces Fed Setaria Grass and Palm \\ Leaves on Biomass and Vermicompost of Worm
}

\author{
B. Brata \\ Jurusan Peternakan, Fakultas Pertanian, Universitas Bengkulu \\ Jl. Raya WR. Supratman, Kota Bengkulu
}

\begin{abstract}
The objective of this research was to evaluate the effect of variety of media added on Kaur cattle feces fed Setaria grass and palm leaves on biomass and vermicompost of worm. Addition of $50 \%$ shaw dust $+50 \%$ feces Kaur cattle fed $(50 \%$ setaria grass $+50 \%$ palm leaves + sakura blok) gave positive impact on worm biomassa production of Pheretima sp, casting quality, and did not affect on worm net shrinkage.
\end{abstract}

Key words: media, feces, Kaur cattle, biomass and vermicompost

\begin{abstract}
ABSTRAK
Tujuan penelitian mengevaluasi pengaruh berbagai madia feses dari sapi kaur yang diberi pakan rumput setaria dan pelepah sawit terhadap biomassa cacing tanah dan kualitas vermikompos cacing tanah. Pemberian media $50 \%$ serbuk gergaji $+50 \%$ feses sapi Kaur yang diberi pakan $(50 \%$ rumput setaria $+50 \%$ pelepah sawit + sakura blok) memberikan dampak positif terhadap produksi biomassa cacing tanah Pheretima sp, kualitas casting, dan tidak memberikan dampak terhadap penyusutan sarang cacing tanah.
\end{abstract}

Kata kunci: media, feces, sapi Kaur, biomass dan vermicompos cacing

\section{PENDAHULUAN}

Cacing tanah merupakan salah satu yang ikut melengkapi khazanah hayati fauna Indonesia dan termasuk kedalam kelompok hewan tingkat rendah, tidak bertulang belakang (invertebrata) yang merupakan kelompok annelida atau cacing bersegmen dimana hewan ini ditemukan pada lingkungan terestrial basah Indonesia (Brata 2009). Menurut Catalan (1981) didunia ini terdapat kira-kira 1800 spesies cacing tanah yang telah didentifikasikan dan diklasifikasikan, dari 1800 spesies cacing tanah ini empat spesies tersebut dikembangkan sebagai ternak komersial. Spesies tersebut adalah Eisenia foetida,
Lumbricus rubellus, Eisenia eugenia dan Pheretima asiatica. Eisenia foetida, Lumbricus rubellus, dan Eisenia eugenia merupakan 80-90\% dari total jumlah cacing tanah komersial di Eropa, Amerika Serikat dan Kanada sedangkan Pheretima asiatica hanya dikembangkan di Asia sebagai cacing tanah komersial.

Budidaya cacing tanah tidak terlalu sulit dan tidak memerlukan biaya yang banyak, sedangkan keuntungan yang didapat dari budidaya cacing cukup tinggi. Cacing tanah digunakan sebagai sumber protein pengganti tepung ikan untuk pakan ternak dan ikan (Minnich,1997). Menurut Palungkung (1999), tepung cacing tanah mengandung protein yang lebih tinggi 
dibandingkan tepung ikan, yaitu mempunyai $67-76 \%$, sedangkan tepung ikan hanya 58\%. Cacing tanah juga mengandung asam amino paling lengkap, berlemak rendah, mudah dicerna dan tidak mengandung racun. Selain itu, cacing tanah juga digunakan sebagai bahan kosmetik dan bahan obat (Rukmana,1999), mengurangi nematoda patogen didalam tanah, pengurai, membuat struktur tanah menjadi lebih baik dan penyubur tanah (Simandjuntak dan Waluyo, 1992).

Pheretima $s p$ termasuk kedalam famili Megasolecidae dengan wilayah penyebaran meliputi Asia Tenggara dan Australia, letak klitelium pada segmen 1416. Pigmen dorsal sama dengan pigmentasi ventral yaitu merah kecoklatan, ukuran tubuh lebih ramping dan panjang serta gerakannya lebih lincah dari pada Eisenia feotida, tubuh cacing dewasa sampai mencapai $11 \mathrm{~cm}$ dari diameter $2 \mathrm{~mm}$. Jumlah segmen 122-153 (Edward dan Lofty, 1972). Menurut Waluyo (1993) cacing tanah mampu merombak bahan organik menjadi pakannya seberat bobot badannya selama 24 jam (Simajuntak dan Waluyo,1992). Tingginya kemampuannya dalam merombak bahan organik dan merendam bau busuk yang menyengat maka cacing tanah juga dapat dimanfaatkan sebagai alternatif untuk mencegah pencemaran lingkungan terutama yang ditimbulkan oleh limbah ternak, rumah tangga dan pasar.

Pertumbuhan cacing tanah dimulai dari kokon, cacing muda (juvenil), cacing produktif dan cacing tua (Palungkung, 1999). Lama pertumbuhan cacing dipengaruhi oleh kondisi lingkungan, cadangan makanan dan jenis cacing tanah (Astuti, 2001). Produksi cacing tanah sangat dipengaruhi oleh media yang digunakan dan pakan yang diberikan dalam proses pertumbuhan dan perkembangbiakan (Haryono, 2003). Gaddie dan Dauglas (1977) melaporkan bahwa habitat cacing tanah secara umum adalah kotoran ternak karena strukturnya yang relatif halus dan kaya akan nutrisi.

Kualitas feses dipengaruhi oleh pakan yang dikonsumsi oleh ternak. Feses sapi kaur hasil yang diberi pakan pelepah kelapa sawit dan rumput alam yang disuplementasikan dengan sakura blok merupakan salah satu produk yang dapat digunakan untuk pakan atau media tumbuh cacing tanah (Jarmuji et al., 2015). Sapi Kaur merupakan sapi lokal yang telah dipelihara oleh penduduk asli Di Kabupaten Kaur Provinsi Bengkulu dalam waktu yang cukup lama (lebih kurang 20 generasi) dan telah mengalami seleksi alam pada lingkungan tropis serta pemeliharaan secara tradisional (Jarmuji et al., 2017).

Kandungan serat kasar pada pelepah sawit dan rumput alam berperan penting untuk media pertumbuhan dan produksi cacing tanah. Pelepah sawit memiliki kandungan protein sebesar 1,9\%, lemak 0,5\% dan lignin 17,4\% (Stur, 1990; Zainudin dan Zahari, 1992). Sedangkan rumput lapang seperti Axonopus compresus, Brachiaria decumbent, Cynodon dactylon, Imperata cylindrical mengandung BK 22,97\%, PK 8,59\%, LK $6,93 \%$, Abu 8,38\%, SK 36,38\%, BETN 
48,31\%, Ca 0,30\%, dan P 0,12\% (Wahyuni, 2008). Sakura blok yang kaya akan kandungan nitrogen bukan protein, energi dan mineral dapat meningkatkan kualitas pakan hijauan yang diberikan pada ternak (Kunju, 1986). Selain dapat memberikan produksi daging pada ternak sapi, pakan juga mempengaruhi kualitas unsur hara yang ada pada feses sapi.

Biomassa dapat ditandai dengan pertumbuhan cacing tanah yang dapat hidup optimal pada media yang sesuai dengan kebutuhan. Bimassa dapat mempengaruhi beberapa factor lingkungan seperti pH, cahaya matahari, aerasi, predator dan ketersediaan bahan organic dalam media. Sedangkan perkembangan cacing tanah ditandai dengan kemampuan cacing tanah dalam menghasilkan kokon. Vermikompos adalah proses dekomposisi bahan organic yang melibatkan kerjasama antara cacing tanah dan mikroorganisme. Vermikompos menghasilkan dua manfaat utama yaitu biomassa cacing tanah dan vermikompos.

Tujuan penelitian mengevaluasi pengaruh berbagai madia feses dari sapi kaur yang diberi pakan rumput setaria dan pelepah sawit terhadap biomassa cacing tanah dan kualitas vermikompos cacing tanah.

\section{MATERI DAN METODE}

Penelitian ini akan dilaksanakan selama 5 bulan mulai bulan Juni sampai Oktober 2016 di Laboratorium Peternakan Fakultas Pertanian, Universitas Bengkulu.

Peralatan yang digunakan dalam penelitian ini, yaitu 25 buah ember plastik dengan diameter $18 \mathrm{~cm}$ dan tinggi $15 \mathrm{~cm}$, semprotan air, kain kasa, timbangan analitik Ohaus kapasitas 310 gram, higrometer, termometer ruang, karung plastik ukuran $10 \mathrm{~kg}$, kantung plastik, sepatu boot, cangkul, botol semprot, sarung tangan, masker, kamera, terpal dan alat tulis.

Bahan - bahan yang digunakan adalah 250 anak cacing Pheretima sp umur 2-3 hari, feses sapi kaur yang telah diberi perlakuan pakan basal berupa pelepah sawit dan rumput lapangan yang disuplementasikan dengan sakura blok, sekam padi, kapur dan air bersih.

\section{Persiapan Pemeliharaan Cacing}

Sebelum penelitian dimulai, dilakukan beberapa tahapan persiapan meliputi pembuatan kandang cacing berupa rak terbuat dari kayu berukuran $2 \mathrm{~m}$ x 0,5 m x 3,5 m dengan 5 tingkat, untuk meletakkan ember yang nantinya akan ditanami cacing tanah.

Pengadaan bibit cacing tanah Pheretima $s p$. dilakukan dengan cara memelihara cacing tanah Pheretima $s p$. dewasa sampai menghasilkan anak. Kemudian anaknya yang berumur 2-3 hari diambil sebanyak 250 ekor sebagai bahan penelitian.

Media tumbuh cacing yang digunakan adalah kotoran sapi kaur, sekam padi dan kapur tembok $\mathrm{CaCO}_{3}$. Perbandingannya yaitu $50 \%$ feses sapi kaur dan 50\% sekam. Kotoran sapi terlebih dahulu dikering-anginkan dan dilakukan penyisiran untuk menghilangkan benda- 
benda anorganik seperti plastik dan logam. Selanjutnya media diaduk dan ditaburi kapur sebanyak 0,2\% dari media hingga merata sambil diberi air bersih sebanyak $60 \%$ dan selanjutnya difermentasi menggunakan kantong plastik selama 21 hari untuk menghilangkan gas-gas yang tidak dikehendaki (Waluyo, 1993). Perhitungan kebutuhan media didasarkan pada bobot badan dewasa cacing tanah (a gram), lama pemeliharaan (b hari), dan kebutuhan cacing tanah terhadap pakan dihitung sebanyak dua kali bobot badan. Dari hasil tersebut dapat dihitung kebutuhan media (Y) menggunakan formula: Y gram = a gram x b x 2 (Brata, 2003).

Setiap ember yang sudah diisi dengan media dimasukkan 10 ekor cacing tanah Pheretima $s p$ umur 2-3 hari. Penanaman cacing tanah dilakukan dengan cara membuat lubang ditengah media dengan kedalaman $5 \mathrm{~cm}$, kemudian lubang ditutup. Untuk menghindari keluarnya cacing tanah dari wadah pemeliharaan, maka tempat pemeliharaan ditutup dengan kain kasa. Selanjutnya setiap ember diberi kode. Penyiraman dilakukan sekali dalam tiga hari dan pembalikan media dilakukan sekali dalam satu minggu (Brata, 2003).

\section{Rancangan Penelitian}

Penelitian ini menggunakan Rancangan Acak Lengkap (RAL) dengan 5 perlakuan dan 5 ulangan. Setiap perlakuan menggunakan media tumbuh cacing yang berasal dari $50 \%$ sekam dan $50 \%$ feses sapi yang diberi pakan berbeda. Setiap ulangan ditanami 10 ekor bibit cacing tanah Pheretima sp umur 2-3 hari. Total cacing yang digunakan adalah 250 ekor.

Perlakuan yang diberikan untuk media hidup cacing adalah sebagai berikut :

$\mathrm{P} 0=100 \%$ feses sapi kaur yang diberi pakan $(100 \%$ Rumput Alam $+50 \%$ pelepah sawit + Sakura Blok)

$\mathrm{P} 1=50 \%$ sekam $+50 \%$ feses hasil dari pemberian pakan $(50 \%$ Rumput setaria $+50 \%$ Pelepah sawit + Sakura Blok)

$\mathrm{P} 2=50 \%$ jerami padi $+50 \%$ feses hasil dari pemberian pakan (50\% Rumput setaria $+50 \%$ Pelepah Sawit + Sakura Blok)

$\mathrm{P} 3=50 \%$ pelepah pisang $+50 \%$ feses hasil dari pemberian pakan $(50 \%$ Rumput Alam + 50\% Pelapah Sawit + Sakura Blok)

$\mathrm{P} 4 .=50 \%$ serbuk gergaji $+50 \%$ feses sapi kaur yang diberi pakan $(0 \%$ rumput setaria+ $50 \%$ pelepah sawit + sakura blok)

\section{Analisis Data}

Data yang diperoleh dianalisis dengan manggunakan sidik ragam anova. Apabila terdapat perbedaan dilakukan uji lanjut dengan uji Duncans Multiple Range Test (Yitnosumarto, 1993)

\section{Variabel yang Diamati}

Bimassa cacing tanah dihitung berdasarkan total bobot induk serta anak dan dilakukan pengamatan di akhir penelitian. Penyusutan sarang cacing tanah Pheretima dilakukan dengan mengukur tinggi sarang di awal penelitian dan 
dikurangi dengan tinggi sarang diakhir pengamatan selama pemelihraan 60 hari. Kualitas Kompos; tekstur, warna dan bau, dilakukan pengamatan kualitas fisik; testur, warna dan bau pada kompos dan diamati pada akhir penelitian sesuai dengan standar Badan Standarisasi Nasional (2011).

\section{HASIL DAN PEMBAHASAN}

\section{Biomassa Cacing Tanah Pheretima sp (g/unit)}

Rataan biomassa cacing Pheretima $s p$ yang dipelihara menggunakan $\mathrm{P} 0=$ $100 \%$ feses sapi kaur yang diberi pakan
(50\% rumput setaria $+50 \%$ pelepah sawit + sakura blok) $\quad \mathrm{P} 1=50 \%$ sekam $+50 \%$ feses sapi kaur yang diberi pakan $(50 \%$ rumput setaria $+50 \%$ pelepah sawit + sakura blok) $\mathrm{P} 2=50 \%$ jerami padi $+50 \%$ feses sapi kaur yang diberi pakan $(50 \%$ rumput setaria $+50 \%$ pelepah sawit + sakura blok) $\mathrm{P} 3=50 \%$ pelepah pisang + $50 \%$ feses sapi kaur yang diberi pakan (50\% rumput setaria $+50 \%$ pelepah sawit + sakura blok) $\quad \mathrm{P} 4=50 \%$ serbuk gergaji $+50 \%$ feses sapi kaur yang diberi pakan (50\% rumput setaria $+50 \%$ pelepah sawit + sakura blok) terlihat pada Tabel 1 .

Tabel 1. Rataan biomassa cacing tanah Pheretima sp selama 60 hari pemeliharaan

\begin{tabular}{|c|c|c|c|c|c|c|}
\hline \multirow{2}{*}{ Perlakuan } & \multicolumn{5}{|c|}{ Ulangan (g/unit) } & \multirow{2}{*}{ Rataan } \\
\hline & 1 & 2 & 3 & 4 & 5 & \\
\hline P0 & 2,24 & 2,09 & 1,52 & 2,26 & 2,38 & $2,10^{\mathrm{c}}$ \\
\hline P1 & 2,76 & 3,19 & 3,05 & 3,60 & 3,37 & $3,19^{\mathrm{b}}$ \\
\hline $\mathrm{P} 2$ & 1,47 & 1,69 & 1,80 & 2,08 & 1,97 & $1,80^{\mathrm{c}}$ \\
\hline P3 & 2,07 & 2,08 & 2,49 & 2,55 & 1,99 & $2,24^{\mathrm{c}}$ \\
\hline $\mathrm{P} 4$ & 3,33 & 4,29 & 4,00 & 3,34 & 3,47 & $3,69^{\mathrm{a}}$ \\
\hline
\end{tabular}

Superskrip berbeda pada kolom yang sama menunjukan beda nyata $(\mathrm{P}<0,05)$

Berdasarkan analisis ragam terlihat campuran media feses sapi kaur yang diberi pakan $50 \%$ rumput setaria $+50 \%$ pelepah sawit + sakura blok berpengaruh sangat nyata $(\mathrm{p}<0,01)$ terhadap produksi biomassa cacing tanah Pheretima $s p$. berturut-turut pada perlakuan P0 2,10 g/unit, P1 3,19 g/unit, P2 1,80 g/unit, P3 2,24 g/unit dan P4, 3.69 g/unit. Ada perbedaan produksi biomassa cacing tanah yang diberi berbagai campuran media disebabkan oleh komposisi media yang diberikan, dan kandungan nitrogen media cacing tanah. Hasil analisis kandungan nitrogen berturut-turut P0 2,26\%, P1
2,36\%, P2 2,25, P3 2.25\% dan P4 2,40\%. Disamping itu pengaruh aerasi akibat pemberian berbagai media dapat meningkatkan produksi biomassa. Aerasi pada media cacing tanah Pheretima $s p$ berfungsi untuk teroksigenasi (bernafas) dan pergerakan cacing tanah Pheretima $s p$ aktif, selain itu agar aerasi menjadi optimal maka adanya penambahan media sekam padi, jerami pada, batang pisang dan serbuk gergaji. sesuai dengan pernyataan Minnich (1977) media yang terlalu padat menyebabkan cacing tanah sulit bernafas dan menurut Waluyo (1993) bahwa aerasi yang baik dapat diciptakan dengan 
penambahan bahan-bahan yang mempunyai kandungan serat kasar yang tinggi seperti sekam padi, dedak padi, serbuk gergaji dan jerami.

Hasil uji lanjut Duncan's Multiple Range Test (DMRT) memperlihatkan produksi biomassa cacing Pheretima $s p$ perlakuan P0 2,10 g/unit tidak berbeda nyata $(\mathrm{P}>0,05)$ dengan $\mathrm{P} 21,80 \mathrm{~g} / \mathrm{unit}$ dan P3 $2.24 \mathrm{~g} / \mathrm{unit}$, namun berbeda sangat nyata $(\mathrm{P}<0,01)$ jika dibandingkan dengan perlakuan P1 3,19 g/unit dan P4 3,69 g/unit. Perlakuan P1 3,19 g/unit berbeda nyata $(\mathrm{P}<0,01)$ jika dibandingkan dengan perlakuan P4 3,69 g/unit.

Tingginya produksi biomassa cacing tanah Pheretima $s p$ dapat dipengaruhi beberapa faktor diantaranya adalah komposisi pakan atau media yang diberikan, dan kandungan nitrogen pakan. Produksi biomassa cacing tanah Pheretima $s p$ yang paling tinggi yaitu perlakuan $\mathrm{P} 4$ 3,69 g/unit dengan kandungan nitrogen media $2.40 \%$. Hal ini disebabkan komposisi pakan yang dberikan mengandung protein yang lebih tinggi dan aerasi pada media cacing tanah Pheretima $s p$ cukup baik sehingga memudahkan cacing tanah Pheretima sp bergerak aktif. Lee (1985) mengemukakan bahwa oksigen untuk respirasi dapat diperoleh dari udara atau dari air yang terioksigenisasi.

Rendahnya produksi biomassa pada perlakuan P2 1,80 g/unit disebabkan oleh komposisi media dan kandungan nitrogen media cacing tanah yang rendah $2.25 \%$. Selain itu juga tidak adanya keseimbangan komposisi media pakan yang diberikan. yang mengakibatkan produksi biomassa cacing tanah Pheretima $s p$ menjadi rendah, sesuai pernyataan dari Roslim et al. (2013) yang menyatakan bahwa pertumbuhan dan laju reproduksi cacing tanah tergantung dari jenis pakan yang dikonsumsi dan sangat erat hubungannya dengan produktivitas biomassa cacing tanah yang dihasilkan.

\section{Penyusutan Sarang Cacing Tanah Pheretima sp}

Berdasarkan hasil pengamatan, penyusutan sarang, rataan penyusutan sarang paling tinggi menyusut adalah perlakuan $\mathrm{P} 4 \quad 2,14 \mathrm{~cm}$ dan penyusutan paling rendah terdapat pada perlakuan P1 0,70 cm. Hasil uji lanjut Duncan's Multiple Range Test (DMRT) memperlihatkan penyusutan sarang cacing tanah Pheretima sp perlakuan P2 $3.66 \mathrm{~cm}$ berbeda nyata $(\mathrm{P}>0,05)$ dengan penyusutan sarang P0 1,38 cm, P1 0.70 , P3 1.64 dan P4 $2.14 \mathrm{~cm}$. Perlakuan P4 $2.14 \mathrm{~cm}$ tidak berbeda nyata $(\mathrm{P}<0,01)$ jika dibandingkan perlakuan $\mathrm{P} 31,64 \mathrm{~cm}$, dan perlakuan $\mathrm{P} 0$ $1,38 \mathrm{~cm}$, namun berbeda nyata $(\mathrm{p}>0.05)$ dengan perlakuan $\mathrm{P} 0.70 \mathrm{~cm}$.

Penyusutan sarang cacing tanah Pheretima sp yang paling tinggi pada perlakuan campuran media jerami padi P2 $3,66 \mathrm{~cm}$ dan yang terendah diperoleh pada perlakuan sekam padi P1 $0.70 \mathrm{~cm}$. Penyusutan media tergantung pada tingkat penyiraman maupun komposisi pakan. Menurut Mashur (2001) penyusutan bahan media atau pakan dipengaruhi oleh kadar air. Bahan media atau pakan yang kadar airnya tinggi menyebabkan penyusutan juga relatif tinggi. Menurut Gaddie dan Doughlass (1977), penyusutan media yang 
terjadi di akhir penelitian dianggap salah satu parameter yang menunjukan adanya aktifitas makan oleh cacing tanah dan mikroorganisme lainnya. Penyusutan terjadi karena adanya kematangan kompos sehingga penurunan bobot/volume pada media. Besarnya penyusutan tergantung pada media. Media sekam padi sangat sulit mengalami penyusutan karena karakteristik sekam padi sedikit keras walaupun sudah difermentasi dibandingkan dengan limbah seperti limbah sayur atau kotoran ternak yang sangat cepat mengalami penyusutan.

Tabel 2. Rataan penyusutan sarang cacing tanah Pheretima sp selama 60 hari $(\mathrm{cm})$

\begin{tabular}{|c|c|c|c|c|c|c|}
\hline \multirow{2}{*}{ Perlakuan } & \multicolumn{5}{|c|}{ Ulangan $(\mathrm{cm})$} & \multirow{2}{*}{ Rataan } \\
\hline & 1 & 2 & 3 & 4 & 5 & \\
\hline P0 & 1,60 & 1,00 & 2,20 & 1,60 & 0,50 & $1,38 b c$ \\
\hline P1 & 0,30 & 0,60 & 0,30 & 2,00 & 0,30 & $0,70 \mathrm{c}$ \\
\hline $\mathrm{P} 2$ & 4,70 & 4,10 & 3,20 & 2,00 & 4,30 & $3,66 \mathrm{a}$ \\
\hline P3 & 2,40 & 1,10 & 1,20 & 3,00 & 0,50 & $1,64 b c$ \\
\hline P4 & 1,70 & 2,70 & 1,50 & 2,30 & 2,50 & $2,14 \mathrm{~b}$ \\
\hline
\end{tabular}

Superskrip berbeda pada kolom yang sama menunjukan beda nyata $(\mathrm{P}<0,05)$

Kualitas Casting Cacing Tanah

Pheretima sp

Pengamatan kualitas casting cacing tanah Pheretima sp selama pemeliharaan sebagian besar memiliki kualitas casting yang sama pada perlakuan P1, P2 dan P3, dan P4 menunjukkan tekstur gembur dan tidak berbau, dan warna kehitaman sedangkan pada perlakuan P0 teksturnya tidak gembur dan warna dan baunya sama dengan perlakuan yang lain.
Casting merupakan kotoran cacing dapat berguna untuk pupuk. Casting ini mengandung partikel-partikel kecil dari bahan organik yang dimakan cacing dan kemudian dikeluarkan lagi. Kualitas casting cacing tanah dapat ditentukan beberapa parameter fisik, kimiawi dan biologis. Secara fisik kualitas casting dapat dilihat berbagai tingkat yaitu kematangan kompos seperti tekstur, warna dan bau.

Tabel 3. Kualitas kompos casting cacing tanah Pheretima sp selama 60 hari

\begin{tabular}{llll}
\hline Pengamatan & Tekstur & Warna & Bau \\
\hline P0 & Tidak Gembur & Kehitaman & Tidak Berbau \\
P1 & Gembur & Kehitaman & Tidak Berbau \\
P2 & Gembur & Kehitaman & Tidak Berbau \\
P3 & Gembur & Kehitaman & Tidak Berbau \\
P4 & Sangat Gembur & Kehitaman & Tidak Berbau \\
\hline
\end{tabular}

Tekstur casting yang dihasilkan adalah gembur kecuali pada perlakuan P0, pada media yang digunakan tidak ditambahkan media yang berserat sebagai control. Menurut Mashur (2001) bahwa casting berwarna hitam memiliki tekstur yang gembur sehingga berguna meningkatkan kemampuan casting dalam 
menyerap unsur hara dan air yang dibutuhkan tanaman. Sebagian besar pada penelitian ini dihasilkan casting yang cukup matang. Casting yaitu proses pengomposan juga dapat melibatkan organisme makro seperti cacing tanah. Kerjasama antara cacing tanah dengan mikro organisme memberi dampak proses penguraian yang berjalan dengan baik. Walaupun sebagian besar proses penguraian dilakukan mikroorganisme, tetapi kehadiran cacing tanah dapat membantu proses tersebut karena bahanbahan yang akan diurai oleh mikroorganisme telah diurai lebih dahulu oleh cacing.

Warna casting cacing tanah Pheretima $s p$ yang dihasilkan pada perlakuan P0, P1, P2, P3 dan P4 semuanya berwarna kehitaman. Hasil ini sesuai menurut Mashur (2001) casting yang baik adalah casting yang berwarna gelap dan kehitaman. Perubahan warna casting menjadi hitam disebabkan oleh terbentuknya senyawa-senyawa humik sebagai hasil proses dekomposisi bahan media atau pakan cacing tanah (Mashur, 2001).

Berdasarkan hasil pengamatan kualitas casting cacing tanah Pheretima $s p$ secara fisik menghasilkan tidak berbau selama pemeliharaan berlangsung, ini karena cacing tanah mampu merombak bau asam menyengat pada media sebelum penanaman cacing tanah. Menurut Mashur (2001) cacing tanah dapat meredam bau busuk yang menyengat dari limbah organik yang digunakan sebagai bahan media atau pakannya. Kualitas kompos yang baik dan optimal yaitu berbau netral (Badan Standarisasi Nasional, 2001).

\section{KESIMPULAN}

Pemberian media 50\% serbuk gergaji $+50 \%$ feses sapi kaur yang diberi pakan $(50 \%$ rumput setaria $+50 \%$ pelepah sawit + sakura blok) memberikan dampak positif terhadap produksi biomassa cacing tanah Pheretima $s p$, kualitas casting, dan tidak memberikan dampak terhadap penyusutan sarang cacing tanah. Berdasarkan hasil penelitian ini, disarankan dalam budidaya cacing tanah Pheretima $s p$ menggunakan pemberian media $50 \%$ serbuk gergaji + $50 \%$ feses sapi Kaur yang diberi pakan $(50 \%$ rumput setaria $+50 \%$ pelepah sawit + sakura blok) dapat digunakan untuk meningkatkan produksi biomassa cacing tanah Pheretima sp, dan kualitas casting, pada pemeliharaan 60 hari.

\section{UCAPAN TERIMA KASIH}

Penelitian ini dilaksanakan atas Hibah Pascasarjana Pengolahan Sumberdaya Alam dan Lingkungan Universitas Bengkulu tahun 2016. Penulis menyampaikan ucapan terima kasih atas Hibah tersebut.

\section{DAFTAR PUSTAKA}

Astuti, N. D. 2001. Pertumbuhan dan Perkembangan Cacing Tanah Lumbricus rubellusdalam Media Kotoran Sapi yang Mengandung Tepung Darah. Fakultas 
Kedokteran Hewan Institut

Pertanian Bogor, Bogor.

Badan Standarisasi Nasional. 2011. Spesifikasi Kompos dari Sampah Organik Domestik SNI 19-70302004. Jakarta.

Brata, B. 2003. Pertumbuhan, Perkembangbiakan dan kualitas Eksmecat dari beberapa spesies Cacing Tanah pada Kondisi Lingkungan yag Berbeda. Disertasi. Pasca Sarjana Institut Pertanian Bogor.

Brata, B. 2009. Faktor yang Mempengaruhi Pertumbuhan dan Perkembangbiakan Cacing Tanah. Penerbit Cetakan Pertama IPB Press. Bogor.

Catalan, G. I. 1981. Earthworms A New Resource of Protein. Philipines Earthworm Center. Philipines.

Edwars, C. A. And J. R. Lofty. 1977. Biology of Earthworms. Chapman and Hall. New York.

Gaddie, R. E. and D. E. Douglas. 1977. Earthworms for Ecology and Profit. Vol. 2. bookworm Publishing Company, Ontario, California.

Haryono. 2003. Pemanfaatan Serbuk Sabut Kelapa dan Ampas Tahu Sebagai Media Pakan Cacing Tanah (Lumbricus rubellus). Prosiding Temu Teknis Fungsional Non Peneliti, Bogor. Pusat Penelitian
Dan Pengembangan Peternakan. 66-73.

Jarmuji, U. Santoso and B. Brata, dan Karyono. 2015. The Effect of feces of Kaur beef palm fround Setaria and sakura block as media on Growth of Eearthworm (Pheretima Sp). Int. Seminar on Promoting Local Resources For Food and Healt, October 12-13, 2015. Bengkulu University, Indonesia. Page 291-294

Jarmuji, U. Santoso and B. Brata, 2017. Effect of Oil Palm Frounds of and Setaria sp as Forages Plus Sakura Block on the Performance and Nutrient Digestibility of Kaur Cattle. Pakistan Journal of Nutrient. ISSN 1680-5194. DOI:10.3923/pjn.2017. pp: 1-7.

Kunju, P. J. G. 1986. Urea Molasses Block Lick: A Feed Supplement for Ruminants. In: Ibrahim, M. N. M. and schiere, J. B. S. (eds). Rice Straw and Related Feeds in Ruminant Rations. Proc. International Workshop Held in Kandy, Sri Langka, $24^{\text {th }}$ to $28^{\text {th }}$ March. 261-274.

Lee, K. E. 1985. Earthworms Their Ecology And Relationships With Soil And Lands Use. CSIRO Division Of Soils Adelaide Academic Press (Harcourt Brace Jovanovich Publishers) Sydney Orlando San Diego New York. London Toronto Montreal Tokyo. 
Mashur. 2001. Kajian Perbaikan Teknologi Budidaya Cacing Tanah Eisenia foetida Savigny Untuk Meningkatkan Produksi Biomassa Dan Kualitas Eksmecat Dengan Memanfaatkan Limbah Organik Sebagia Media [Disertasi]. Bogor. Program Studi Ilmu Ternak Program Pascasarjana Institut Pertanian Bogor.

Minnich, J. 1997. The Earthworm Book How to Rise and Use Earthworm for Your Farm and Garden. Rodale PRESS Emmaus, PA. New York, 199-127.

Palungkung, R. 1999. Sukses Beternak Cacing Tanah Lumbricus rubellus. Penebar Swadaya, Jakarta. 1-80.

Roeslim, D. I., Nastiti, D. S. dan Herman. 2013. Karakter Marfologi dan Pertumbuhan Tiga Jenis Cacing Tanah lokal Pekanbatu pada dua Macam Media Pertumbuhan. Biosaintifika. 5(1). 1-9.

Rukmana. 1999. Budidaya Cacing Tanah. Kanisius. Yogyakarta.

Sturt, W. W. 1990. Methodology for Establishing Selection Criteria for Forage Species Valuation. in Proc. Integrated Tree Cropping and Small Ruminant Production System. SR-CRSP. Univ. California Davis, USA. Page. 1023.
Simanjuntak, A. K dan D. Waluyo. 1992. Cacing Tanah . Budidaya dan Pemanfaatannya. PT. Penebar Swadaya. Jakarta.

Wahyuni, D. S. 2008. Fermentabilitas dan Degradabilitas In Vitro serta Produksi Biomassa Mikroba Ransum Komplit Kombinasi Rumput Lapang, Konsentrat dan Suplemen Kaya Nutrien. Skripsi. Ilmu Nutrisi dan Teknologi Pakan, Fakultas Peternakan, Institut Pertanian Bogor, Bogor.

Waluyo, D. 1993. Pengaruh Kapur Terhadap Perkembangan Tubuh dan Klitelium, serta Kadar Protein dan Asam Amino pada cacing tanah. Tesis Program Pasca Sarjana Institut Pertanian Bogor. Bogor.

Yitnosumarto, S. 1993. Perancangan Percobaan, Analisis dan Interprestasinya. Gramedia Pustaka Utama. Yogyakarta.

Zainudin, A. T and M. W. Zahari. 1992. Research on Nutrition and Feed Resaurces to Enhance Liverstok Production in Malaysia. Proc. Utilization of Feed Resaurces in Relation to Nutrition and Physiology of Ruminants in The Tropics. Trop. Agric. Res. 25: 925. 